\title{
Author Correction: Recurrent PTPRT/JAK2 mutations in lung adenocarcinoma among African Americans
}

Khadijah A. Mitchell (1), Noah Nichols (1), Wei Tang (1), Jennifer Walling (1), Holly Stevenson (D), Marbin Pineda, Roxana Stefanescu, Daniel C. Edelman, Andrew T. Girvin, Adriana Zingone, Sanju Sinha, Elise Bowman, Emily L. Rossi, Rony F. Arauz (D), Yuelin Jack Zhu, Justin Lack, Elizabeth Weingartner, Joshua J. Waterfall(D), Sharon R. Pine (1), John Simmons, Paul Meltzer \& Bríd M. Ryan (1)

Correction to: Nature Communications https://doi.org/10.1038/s41467-019-13732-y, published online 16 December 2019.

The original version of this Article contained an error in the spelling of the author Joshua J. Waterfall, which was incorrectly given as Josh Waterfall. This has now been corrected in both the PDF and HTML versions of the Article.

Published online: 30 January 2020

\footnotetext{
(c) (i) Open Access This article is licensed under a Creative Commons Attribution 4.0 International License, which permits use, sharing, adaptation, distribution and reproduction in any medium or format, as long as you give appropriate credit to the original author(s) and the source, provide a link to the Creative Commons license, and indicate if changes were made. The images or other third party material in this article are included in the article's Creative Commons license, unless indicated otherwise in a credit line to the material. If material is not included in the article's Creative Commons license and your intended use is not permitted by statutory regulation or exceeds the permitted use, you will need to obtain permission directly from the copyright holder. To view a copy of this license, visit http://creativecommons.org/licenses/by/4.0/.
}

(C) The Author(s) 2020 